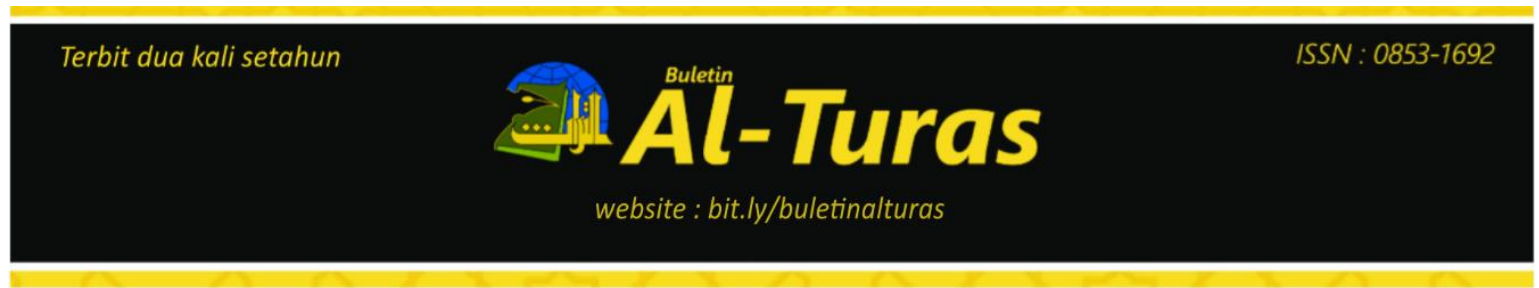

\title{
Integrasi Interpretasi Makna Kata Khalifah: Respon terhadap Gerakan Hizbuttahrir di Indonesia
}

\author{
Muhammad Shodiq \\ Sekolah Tinggi Filsafat Islam Sadra \\ shodiqm313@gmail.co.id
}

\author{
Mauidlotun Nisa \\ Universitas Islam Negeri Syarif Hidayatullah \\ mauidlotun.nisa@uinjkt.ac.id
}

\begin{abstract}
Abstrak
Tulisan ini berupaya mengintegrasikan interpretasi tekstual dan kontekstual kata Khalifah QS. AlBaqarah ayat 30 dalam merespon gerakan Hizbuttahrir di Indonesia. Penelitian ini menggunakan konsep Ali Reza'i Isfahani dalam bukunya The Logic of the Exegesis of the Quran) tentang tahapan berfikir kontekstual integratif mulai dari konteks literal, kronologi, hukum, hingga konteks kontemporer. Setelah itu, disimpulkan dengan tahapan mulai dari memahami tujuan ayat, melepaskan subjektifitas (lokalitas) tempat, masa, dan pelaku, mengambil kaidah universal Ayat, dan menerapkan pada objek baru. Data penelitian ini adalah interpretasi kata khalifah dengan metode jami' (komprehensif) yang menalar logika interpretasinya berdasarkan prinsip-prinsip metodologi integratif seperti Thaba'thaba'i, Makarim Shirazi, Javadi Amuli, Reza'i Isfahani, Fakhruddin Al-Razi, dan M. Quraish Shihab. Interpretasi kontekstual integratif kata Khalifah pada QS. Al-Baqarah [2]: 30 adalah bahwa manusia pilihan sebagai khalifatullah bukan manusia secara umum tapi adalah manusia terpilih yang suci yang senantiasa ada dalam setiap generasi umat manusia, dan dalam hal ini di ayat yang dimaksud terimplemantasi dalam wujud Nabi Adam As. Dengan demikian interpretasi kata khalifah tidak relevan dengan konsep khilafah Hizbuttahrir di Indonesia.
\end{abstract}

Kata kunci: integrase; interpretasi; khalifah; hizbuttahrir

\section{Abstract}

This paper seeks to integrate textual and contextual interpretations of the word Khalifah QS. AlBaqarah verse 30 in response to the Hizbuttahrir movement in Indonesia. This research uses the concept of Ali Reza Esfaha in his book The Logic of the Exegesis of the Quran), that is mentioned about the stages of integrative contextual thinking starting from the literal context, chronology, law, to the contemporary context. After that, it is concluded with the stages starting from understanding the purpose of the verse, releasing the subjectivity (locality) of the place, time, and actor, taking the universal rules of the verse, and applying it to the new object. Therefore, this research data is the interpretation of the word caliph with jami '(comprehensive) method which makes sense of the logic of interpretation based on the principles of integrative methodology such as Thaba'thaba'i, Makarim Shirazi, Javadi Amuli, Reza'i Isfahani, Fakhruddin Al-Razi, and M. Quraish Shihab. The integrative contextual interpretation of the Khalifah words in QS. Al-Baqarah [2]: 30 is that the chosen human being as khalifatullah is not a human being in general but is a chosen holy person who is always present in every generation of humanity, and in this case the verse in question is implemented in the form of the Prophet Adam. Thus the interpretation of the word caliph is not relevant to the Khilafah concept of the Hizbuttahrir in Indonesia.

Keywords: integration; interpretation; , khalifah; hizbuttahrir 


\section{A. Pendahuluan}

Hizbuttahrir merupakan frasa yang berasal dari bahasa Arab, Hizb yang berarti 'partai' dan al-tahrir yang berarti 'pembebasan'.2 Jadi, Hizbuttahrir secara bahasa berarti Partai (untuk) Pembebasan. Dalam buku yang berjudul Hizbuttahrir, Hizbuttahrir didefiniskan sebagai partai politik, ideologinya Islam, maka politik adalah aktivitasnya sedangkan Islam adalah ideologinya. Hizbuttahrir adalah perhimpunan (organisasi) yang bersifat politik, bukan organisasi kerohanian, bukan organisasi ilmiah, bukan organisasi pendidikan dan bukan pula organisasi sosial."3

Aktivitas dan kegiatan Hizbuttahrir keseluruhannya adalah aktivitas politik ${ }^{4}$ Hizbuttahrir adalah sebuah partai politik yang beridiologi Islam, bukan organisasi kerohanian, bukan lembaga ilmiah, bukan lembaga pendidikan dan bukan pula lembaga sosial yang bermaksud membangun kembali Daulah Khilafah Islamiyah di muka bumi. ${ }^{5}$ Hizbuttahrir merupakan partai yang bertujuan untuk pembentukan pemerintah, menerapkan Islam secara komprehensif dan membawa pesannya ke seluruh dunia. ${ }^{6}$ Dari semua argumentasi di atas, dapat disimpulkan bahwa Hizbuttahrir adalah partai politik, bahkan satu-satunya partai politik Islam di dunia Internasional. Hizbuttahrir didirikan oleh Taqiyyuddin al-Nabhani pada 28 Jumada al-Tsaniah $1372 \mathrm{H}$., atau bertepatan dengan tanggal 14 Maret $1953 \mathrm{M}$ atau $1372 \mathrm{H}$. di AlQuds $^{7}$ (Baitul Maqdis), Palestina dan baru memasuki Indonesia tahun 1980-an

\footnotetext{
${ }^{1}$ A. W. Munawwir, "Kamus Al-Munawwir" (Surabaya: Pustaka Progresif, 1997), 259.

${ }^{2}$ A. W. Munawwir, 252.

${ }^{3}$ Abdurrahman al-Dimishqiyyah, Hizb al-Tahrir (Lebanon: Dar al-Ummat, 1985), 4.

${ }^{4}$ Abdurrahman al-Dimishqiyyah, 22.

5 "Website Resmi HTI," diakses 14 Agustus 2018, https://hizbuttahrir.org/.
}

dan kemudiaan diberi nama Hizbut Tahrir Indonesia.

Bahkan karena gerakan Khilafah nya yang sangat masif di Indonesia untuk menjadikan Indonesia sebagai Negara Islam, maka Hizbuttahrir popular dengan akronim HTI (Hizbut Tahrir Indonesia). Tahrir Indonesia (HTI). HTI di Indonesia adalah satu-satunya organisasi Islam yang dikendalikan oleh suatu kepemimpinan asing yang agendanya secara fundamental transnasional yang tidak memiliki andil dalam perjuangan mengusir penjajah dari bumi Indonesia, mempertahankan kemerdekaan dan HTI sama sekali tidak terlibat dalam perintisan berdirinya NKRI, namun paling lantang memperjuangkan khilafah islamiyyah. NKRI adalah hasil kesepakatan final bersama seluruh rakyat Indonesia dalam mendirikan negara, namun HTI justru berjuang untuk mendirikan negara berbentuk khilafah islamiyyah. Hal ini terlihat jelas bahwa HTI telah mengingkari konsensus kebangsaan (almu'ahadah al-wathaniyyah) dan melawan kesepakatan final seluruh rakyat Indonesia dan Negara Kesatuan Republik Indonesia.

$\begin{array}{ccr}\text { Menurut } & \text { HTI, } & \text { kewajiban } \\ \text { pembentukan } & \text { khilafah } & \text { dalam }\end{array}$
pemerintahan negara telah disepakati oleh seluruh ulama dari seluruh mazhab. Tidak ada perbedaan pendapat dalam masalah ini, kecuali dari minoritas ulama yang tidak pendapatnya tidak otoritatif. Bahkan Abdul Qadim Zallum, pimpinan kedua Hizbuttahrir menyatakan bahwa mengangkat seorang khalifah adalah kewajiban bagi umat Islam di seluruh

${ }^{6}$ Hizbut Tahrir Britain, The Method to ReEstasblish the Khilafah and Resume the Islamic Way of Life (London: al-Khilafah Publication, 2000), 90.

${ }^{7}$ Abdurrahman al-Dimishqiyyah, Hizb al-Tahrir, 17. 
dunia. Kewajiban ini bersifat mutlak dan pasti, yang jika tidak dilakukan akan dicatat sebagai sebuah kemaksiatan dan dosa besar dan nanti diazab oleh Allah dengan azab yang sangat pedih. ${ }^{8}$

Mereka mengklaim bahwa kewajiban atas Khilafah bukan hanya pendapat Hizbuttahrir, tapi pendapat seluruh ulama. Dengan percaya diri mereka menguatkan klaimnya dengan mengutip pendapat Imam Ibnu Hazm yang menyebutkan bahwa Ahlus Sunnah, Murji ah, Syiah, dan Khawarij sepakat atas wajibnya Khilafah. ${ }^{9}$ Bahkan mereka menyebutkan kekuatan atas klaimnya dengan menyebutkan bahwa empat mazhab Ahlus Sunnah, menurut Abdurrahman al-Jaziri telah sepakat bahwa khilafah hukumnya fardhu. Artinya, Umat Islam harus mempunyai seorang Khalifah yang akan menegakkan syiar-syiar agama dan menolong orang yang dizalimi dari perbuatan orang zalim. Mereka juga sepakat bahwa kaum muslimin dalam waktu yang sama di seluruh dunia, tidak boleh mempunyai dua imam, baik keduanya sepakat atau bertentangan. Mereka juga menyebutkan dalil atas klaimnya bahwa para ulama menyatakan dalil-dalil kewajiban Khilafah itu ada 4 (empat), yaitu : Alqur`an, Sunnah, Ijma' Shahabat, dan Qa'idah Shar'iyyah.

Dalil Alquran, yang paling sering digunakan HTI dan para pegiat khilafah lainnya untuk melegitimasi sistem politik sesuai tafsir mereka adalah QS. Alıุ̧Baqarah [2]: 30,

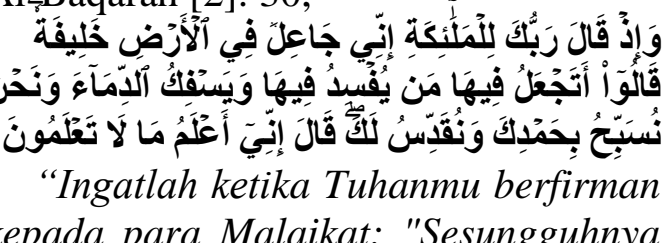

\footnotetext{
${ }^{8}$ Abdul Qadim Zalum, Nizam al-Hukm fi alIslam (Dar al-Ummah, 2002), 34.

'Ibnu Hazm, Al-Fashl fi Al-Milal wa al-Ahwa' wa al-Nihal (Beirut: Dār Kutub al-'Ilmiyyah, 1999), 78.
}

Aku hendak menjadikan seorang khalifah di muka bumi". Mereka berkata: "Mengapa Engkau hendak menjadikan (khalifah) di bumi itu orang yang akan membuat kerusakan padanya dan menumpahkan darah, padahal kami senantiasa bertasbih dengan memuji Engkau dan mensucikan Engkau?" Tuhan berfirman: "Sesungguhnya Aku mengetahui apa yang tidak kamu ketahui".

Padahal ayat ini yang menyebut kata khalifah bermakna pengganti Allah (khalifatullah) dalam kemakmuran bumi secara menyeluruh melalui peran manusia yang diperankan oleh Nabi Adam As. dengan berbagai kesempurnaan yang melekat padanya. Jadi, ayat tersebut sama sekali tidak menunjukkan makna khalifah yang sempit sebagai entitas kepemimpinan politik dalam menegakkan sistem khilafah Islam yang bersifat internasional (al-khilafah al-islamiyyah al-'alamiyyah).

Hanya HTI saja yang mewajibkan penegakan sistem khilafah dengan kewajiban mengangkat satu orang khalifah, di dunia ini hanya boleh ada satu kekhilafahan saja. Dalam hal ini konsep mereka terungkap sebagaimana yang dinukil dari buku pedoman yang diedarkannya:"Semua orang muslim wajib berada di dalam satu negara dan (wajib) hanya memiliki satu khalifah, tidak ada yang selainnya. Menurut syara' haram bagi orang-orang muslim memiliki lebih banyak dari satu negara di dunia ini dan (haram) memiliki lebih dari satu khalifah." 10

Di antara lain dalil yang dipakai juga sebagaimana firman Allah SWT QS. AlNisa [4]: 59 "Hai orang-orang yang

\footnotetext{
${ }^{10}$ Hizbuttahrir, Ajhizah Daulah al-Khilifah fi alHukm wa al-Idarah (Beirut-Lebanon: Dar alUmmah, 2005), 37.
} 
beriman, taatilah Allah dan taatilah Rasul (Nya), dan ulil amri di antara kamu. Kemudian jika kamu berlainan pendapat tentang sesuatu, maka kembalikanlah ia kepada Allah (Al Quran) dan Rasul (sunnahnya), jika kamu benar-benar beriman kepada Allah dan hari kemudian. Yang demikian itu lebih utama (bagimu) dan lebih baik akibatnya."

Argumentasi mereka atas ayat di atas adalah bahwa ayat ini telah memerintahkan kaum muslimin untuk mentaati Ulil Amri di antara mereka, yaitu para Khalifah. Perintah untuk mentaati Ulil Amri ini adalah dalil wajibnya mengangkat Ulil Amri, sebab tak mungkin Allah SWT memerintahkan umat Islam untuk mentaati sesuatu yang tidak ada. Dengan kata lain, perintah mentaati Ulil Amri ini berarti perintah mengangkat Ulil Amri. Jadi ayat ini menunjukkan bahwa mengangkat seorang Khalifah bagi umat Islam adalah wajib hukumnya. ${ }^{11}$

Dalil Alquran lain yang mereka bawa adalah firman Allah SWT dalam QS. AlMaidah [5]:48 "Maka putuskanlah perkara mereka menurut apa yang diturunkan Allah dan janganlah kamu mengikuti hawa nafsu mereka dengan meninggalkan kebenaran yang telah datang kepadamu.".

Ayat di atas diargumentasikan oleh mereka sebagai dalil bahwa Allah telah memerintahkan Rasulullah SAW untuk memberikan keputusan hukum di antara kaum muslimin dengan apa yang diturunkan Allah (Syariah Islam). Bahkan mereka dengan kuat mengutip kaidah ushul fiqih yang menetapkan bahwa perintah kepada Rasulullah SAW hakikatnya adalah perintah kepada kaum muslimin, selama tidak dalil yang mengkhususkan perintah itu kepada

${ }^{11}$ Abdullah 'Umar Sulaiman Al-Dumaiji, Abdullah 'Umar Sulaiman Al-Dumaiji, Al-
Rasulullah SAW saja. Dalam hal ini mereka menyimpulkan bahwa tidak ada dalil yang mengkhususkan perintah ini hanya kepada Rasulullah SAW, maka berarti perintah tersebut berlaku untuk kaum muslimin seluruhnya hingga Hari Kiamat nanti. Perintah untuk menegakkan Syariah Islam tidak akan sempurna kecuali dengan adanya seorang Imam (Khalifah). Maka ayat di atas, dan juga seluruh ayat yang memerintahkan berhukum dengan apa yang diturunkan Allah, hakikatnya adalah dalil wajibnya mengangkat seorang Imam (Khalifah), yang akan menegakkan Syariah Islam itu. ${ }^{12}$

Dalil Alquran lainnya, adalah ayatayat yang memerintahkan qisas (QS Al Baqarah: 178), hudud (misal had bagi pelaku zina dalam QS An Nur: 2; atau had bagi pencuri dalam QS Al Maidah : 38), dan ayat-ayat lainnya yang pelaksanaannya bergantung pada adanya seorang Imam (Khalifah). Ayat-ayat semisal ini, berarti adalah dalil untuk wajibnya mengangkat seorang Imam (Khalifah), sebab pelaksanaan ayat-ayat tersebut bergantung pada keberadaan Imam itu.

Dalil Hadis, banyak sekali, antara lain sabda Nabi SAW : "Barangsiapa yang mati sedangkan di lehernya tidak ada baiat (kepada seorang imam/khalifah), maka matinya adalah mati jahiliyah." (HR Muslim, no 1851). Dalalah (penunjukkan makna) dari hadis di atas jelas, bahwa jika seorang muslim mati jahiliyyah karena tidak punya baiat, berarti baiat itu wajib hukumnya. Sedang baiat itu tak ada kecuali baiat kepada seorang imam (khalifah). Maka hadis ini menunjukkan bahwa mengangkat seorang imam

Imamah Al-'Uzama' 'Inda Ahli al-Sunnah wal Jama'ah 1987. (Kairo, 1987), 49.

12 Abdullah 'Umar Sulaiman Al-Dumaiji, 49. 
(khalifah) itu wajib hukumnya. ${ }^{13}$ Dalil lain dari Hadis misalnya sabda Nabi SAW : "Jika ada tiga orang yang keluar dalam suatu perjalanan, maka hendaklah mereka mengangkat salah seorang dari mereka untuk menjadi amir (pemimpin)." (HR. Abu Dawud).

Tidak sampai di situ, mereka bahkan mengutip Ibnu Taimiyah yang mengatakan bahwa jika Islam mewajibkan pengangkatan seorang amir (pemimpin) untuk jumlah yang sedikit (tiga orang) dan urusan yang sederhana (perjalanan), maka berarti Islam juga mewajibkan pengangkatan amir (pemimpin) untuk jumlah yang lebih besar dan untuk urusan yang lebih penting. ${ }^{14}$ Mereka menyimpulkan bahwa untuk umat Islam yang jumlahnya lebih dari satu miliar seperti sekarang ini, dan demi urusan umat yang lebih penting dari sekedar perjalanan, seperti penegakan hukum Syariah Islam, perlindungan umat dari penjajahan dan serangan militer kafir penjajah, maka mengangkat seorang Imam (Khalifah) adalah wajib hukumnya. Adapun dalil Ijma' Shahabat, telah disebutkan oleh para ulama, misalnya Ibnu Khaldun sebagai berikut: "Mengangkat seorang imam (khalifah) wajib hukumnya, dan kewajibannya dapat diketahui dalam Syariah dari ijma' (kesepakatan) para shahabat dan tabi' in..." 15 Ibnu Hajar AlHaitami juga berkata : "Ketahuilah juga, bahwa para shahabat -semoga Allah meridhai mereka- telah bersepakat bahwa mengangkat seorang imam (khalifah) setelah berakhirnya zaman kenabian adalah wajib, bahkan mereka menjadikannya sebagai kewajiban

\footnotetext{
${ }^{13}$ Abdullah 'Umar Sulaiman Al-Dumaiji, 49.

${ }^{14}$ Ibnu Taimiyah, Al-Khilfah wa al-Muluk dalam Majmu' Fatawa, t.t., 11.

${ }^{15}$ Ibnu Khaldun, Muqaddimah (Beirut: Dar alQalam, 1984), 191.
}

paling penting ketika mereka menyibukkan diri dengan kewajiban itu dengan meninggalkan kewajiban menguburkan jenazah Rasulullah SAW." 16

Adapun dalil Qaidah Syar'iah, adalah kaidah yang mereka klaim berbunyi : "Jika suatu kewajiban tidak terlaksana kecuali dengan sesuatu, maka sesuatu itu wajib pula hukumnya." Mereka menegaskan bahwa telah diketahui bahwa terdapat kewajiban-kewajiban syariah yang tidak dapat dilaksanakan secara sempurna oleh individu, seperti kewajiban melaksanakan hudud, seperti hukuman had bagin pelaku zina dalam QS. An Nuur: 2; atau hukuman had bagi pencuri dalam QS. Al-Maidah [5]: 38, kewajiban jihad untuk menyebarkan Islam, kewajiban memungut dan membagikan zakat, dan sebagainya. Kewajiban-kewajiban ini tak dapat dan tak mungkin dilaksanakan secara sempurna oleh individu, sebab kewajiban-kewajiban ini membutuhkan suatu kekuasaan (sulthah), yang tiada lain adalah Khilafah. Maka kaidah syariah di atas juga merupakan dalil wajibnya Khilafah. ${ }^{17}$

Untuk merespon interpretasi HTI di atas, penting untuk diungkap secara sistematis penafsiran kata khalifah dengan logika kontekstual integratife dengan mendialogkan teks dan konteks, mulai konteks teks, konteks sejarah, hingga konteks kontemporer. Dalam menafsirkan kata khalifah, tidak mungkin terlepas dari terma khilafah yang menjadi bahasa politik Islam terpopuler. Hal ini disebabkan oleh banyaknaya kata tersebut dari berbagai

\footnotetext{
${ }^{16}$ Ibnu Hajar Al-Haitami, Al-Sawa'iq alMuhriqah (Beirut: Dar al-Kutub 'Ilmiyyah, 2000), 7.

${ }^{17}$ Abdullah 'Umar Sulaiman Al-Dumaiji, Abdullah 'Umar Sulaiman Al-Dumaiji, AlImamah Al-'Uzama' 'Inda Ahli al-Sunnah wal Jama'ah 1987., 49.
} 
derivasi yang disebutkan dalam AlQuran maupun Hadis yang memiliki makna luas dan mandalam. Terma khilafah merupakan terma yang menjadi bukti adanya relasi interaktif antara Tuhan, manusia, dan alam melalui hukum syariat. Terma khilafah juga mengintegrasikan antara antara dunia dan akhirat, antara politik dan agama, dan antara ruh dengan akal. Bahkan terma khilafah mampu menguak idealisme peradaban Islam, khususnya Indonesia sebagai Negara Kesatuan Republik Indonesia. ${ }^{18}$

\section{B. Metode}

Penelitian ini menggunakan konsep Ali Reza'i Isfahani dalam bukunya The Logic of the Exegesis of the Quran. Ia menyebutkan tentang tahapan berfikir kontekstual integratif mulai dari konteks literal, kronologi, hukum, hingga konteks kontemporer. Setelah itu, disimpulkan dengan tahapan mulai dari memahami tujuan ayat, melepaskan subjektifitas (lokalitas) tempat, masa, dan pelaku, mengambil kaidah universal Ayat, dan menerapkan pada objek baru. Oleh kerana itu data tulisan ini adalah interpretasi kata khalifah dengan metode jami' (komprehensif) yang menalar logika interpretasinya berdasarkan prinsip-prinsip metodologi integratif seperti Thaba'thaba'i, Makarim Shirazi, Javadi Amuli, Reza'i Isfahani, Fakhruddin Al-Razi, dan M. Quraish Shihab. Data primer penelitian ini adalah Mantiq Tafsir Quran, Mabani wa qawa'id tafsir Quran (The Logic of the Exegesis of the Quran) karya Mohammad 'Ali Reza'i Isfahani. Sedangkan data sekunder penelitian ini adalah kitab tafsir karya tekstualis dan kontekstualis serta karya tafsir Jami' (integratif atau komprehensif) seperti

\footnotetext{
${ }^{18}$ Ahmad Ramadlan Ahmad, Al-Khilafah fi alHadlarah al-Islamiyyah (Jedah: Dar al-Bayan Al-'Arabiyyah, t.t.), 5.
}

Tafsir al-Mizan, Tafsir al-Manar, tafsir al-Amthal dan karya tafsir lainnya yang relevan dengan penelitian ini, Penelitian ini menggunakan pendekatan sosiologi, sejarah, politik, budaya, dan pendekatan fenomenologi.

\section{Temuan dan Pembahasan \\ Logika Kontekstual Integratif Penafsiran Kata Khalifah}

Yang dimaksud kontekstualisasi dalam tulisan ini adalah bagaimana kata khalifah dijelaskan dalam 3 konteks yaitu konteks literal, konteks sejarah, dan konteks kontemporer. Tiga konteks ini kemudian diintegrasikan dalam pengambilan penafsiran yang kontekstual-integratif. Oleh karena itu, dalam memahami QS. Al-Baqarah [2]: 30 secara kontekstual dan integratif, ada 4 tahapan yang harus dilalui dalam memahami konteks ayat tersebut sebagaimana berikut.

\section{Konteks Literal}

Konsep khalifah yang eksklusif dan sakral telah mengalami reduksi makna seiring dengan dinamika politik masyarakat Islam, sejak wafatnya Nabi Muhammad Saw hingga wafatnya Ali ibn Abi Thalib. Selama 29 tahun, khalifah menjadi sakral disematkan kepada figur yang menduduki posisi pengganti Nabi Muhammad dalam kepemimpinan umat Islam yang terdiri dari para sahabat Abu Bakar, Umar Ibnu Khattab, Utsman Ibn Affan dan Ali Ibnu Abi Thalib yang popular dengan khulafaurrasyidin (para khalifah yang bijaksana). Tidak hanya sebatas kala itu, konsep Khalifah bahkan terus tereduksi lebih jauh lagi yang hanya sebatas pada para pemimpin atau penguasa setelah Khulafaurrasyidin meski bentuk kekuasaannya terpolarisasi menjadi 
sistem monarki dari dinasti Umawi, Abbasi, hingga dinasti Uthmani selama 1261 tahun. Bahkan polarisasai tersebut menjadikan para raja menyematkan gelar khalifah kepada dirinya yang justru sandaran legitimasi syar'i atas kekuasaannya dengan menggunakan ayat-ayat yang sama tentang kedudukan khilafah. Kini termasuk para penggagas khilafah di era kontemporer tidak lepas dari modus dalam konteks upaya mendidrikan apa yang mereka sebut dengan Dawlah Islamiyyah, bahkan membawa- sakralitas nama Khalifatullah sebagaimana mana hakikinya yang berarti pengganti atau wakil Allah di bumi. ${ }^{19}$

Oleh karena itu pada konteks literal, penting dibahas dan diungkap makna kata khalifah secara epistemologis, mulai dari makna etimologi, terminologi, dan operasionalkontekstual kata itu. Ditinjau dari sisi bahasa Arab, kata "khalifah (خليفة)" adalah bentuk nomina singular yang berarti "orang yang menggantikan dan representator dari yang lain dalam urusannya bisa saja ketika berada bersamanya atau setelahnya" dengan demikian khilafah (خلافة) adalah niyabah penggantian seseorang dari yang lain.. ${ }^{20}$, sedangkan bentuk jamak (plural) nya adalah "khalaif (خلائف)". Adapun kata “'khulafa' (خلفاء) “ merupakan bentuk plural dari kata

19 'Ali Ibn Muhammad Al-Mawardi, Al-Ahkam al-Sultaniyyah wa al-Wilayah al-Diniyyah (Kuwait, 1989), 4; Ahmad Ibn 'Ali AlQalaqsandi, Ma'atsir al-Inafah fi Ma'alim alKhilafah (Kuwait, 1964), 8-12.

${ }^{20}$ Al-Raghib Al-Isfahani, Mu'jam Mufradat Alfazh Al-Qur'ani (Damaskus: Dar al-Qalam, 1416), 294; Ibnu Faris dan Ahmad Ibn Zakaria, Maqayis al-Lugahahro (Kairo: Dar al-Hadith, 2008), 267.

${ }^{21}$ Muhammad Ibrahim al-Khafnawi, Mu'jam Gharib al-Fiqh wa al-Ushu (Kairo: Dar alHadith, 2009), 233.

${ }^{22}$ Al-Raghib Al-Isfahani, Mu'jam Mufradat Alfazh Al-Qur'ani, 123; Al-Samin al-Halibi, "khalif (خليف)" tanpa huruf " $T a$ " Marbuthah" karena kata ini bermakna nomina subjektif atau ism fa'il (kata benda yang menunjukkan pelaku suatu perbuatan). Kata "khalif" ini merupakan asal kata dari "khalifah) ( خليفة )." Penambahan huruf “ $T a$ ' Marbuthah' (') pada "khalif (خليف) bermakna mubalaghah (bentuk pernyataan yang dilebihkan/pleonastic) sehingga menjadi sifat spesifik bagi orang tertentu. ${ }^{21}$

Hasil proses pemetaan derivasi kata Khalifah dalam Al-Quran ditemukan 127 kata yang menjadi derivasi kata Khalifah. Artinya, sebanyak 127 kali kata tersebut dalam beragam redaksi dan derivasi pada surah tertentu sebagaimana pembagiannya pada lampiran 2. Meski demikian, kata khalifah yang secara langsung disebutkan dengan bentuk nomina berpola khalifah خليفة hanya diliterasikan 9 kali oleh Alquran sebagaimana pada tabel di bawah ini. ${ }^{22}$ Tabel 1. Literasi Kata Khalifah Bentuk Nomina Berpola khalifah

\begin{tabular}{|c|c|c|c|}
\hline No. & Bentuk & Literasi & Posisi \\
\hline 1. & Singular & 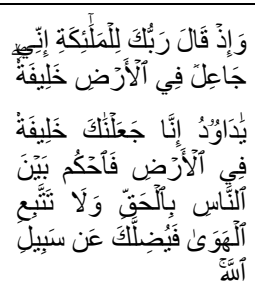 & $\begin{array}{l}\text { QS. Al- } \\
\text { Baqarah [2]: } \\
30\end{array}$ \\
\hline 2. & Plural & 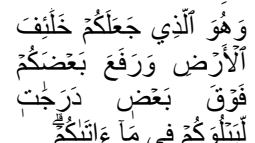 & $\begin{array}{l}\text { QS. Al- } \\
\text { An'am [6]: } \\
165\end{array}$ \\
\hline
\end{tabular}

'Umdah al-Huuffazh (Beirut: Dar al-Kutub, 2000), 205; Al-Fairuzabadi, Basair Dhawi alTamyiz fi Lathaifi Kitab al-'Aziiz (Al-Majlis alA'la li al-Shu'un al-Islamiyyah, 1996), 15; Muhammad Hasan Jabal, Al-Mu'jam AlIshtiqaqi al-Muasshal (Beirut: Dar al-Fikr, 2000), 75; Al-Jauhari, Al-Sahhah fi al-Lughah (Kairo: Dar al-Hadith, t.t.); Ibn Manzur, "Lisan al-'Arab" (Mesir: Dar al-Misriyyah, t.t.), 205; Al-Fairuzabadi, Al-Qamus al-Muhith (Muassasah al-Risalah, 2009), 110; Ibn Faris, Maqayis al-Lughah (Beirut: Dar al-Fikr, t.t.), 267. 


\begin{tabular}{|c|c|c|}
\hline 3. & 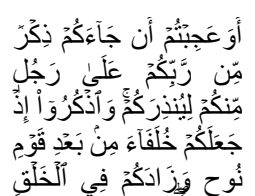 & $\begin{array}{l}\text { QS. Al-A'raf } \\
\text { [7]: } 69\end{array}$ \\
\hline 4. & 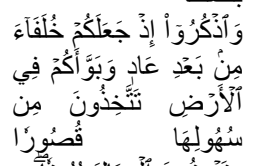 & $\begin{array}{l}\text { QS. Al-A'raf } \\
\text { [7]: } 74\end{array}$ \\
\hline 5. & 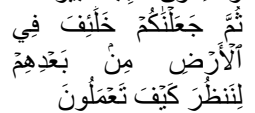 & $\begin{array}{l}\text { QS. Yunus } \\
\text { [10]: } 14\end{array}$ \\
\hline 6. & 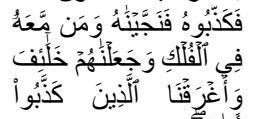 & $\begin{array}{l}\text { QS. Yunus } \\
\text { [10]: } 73\end{array}$ \\
\hline 7. & 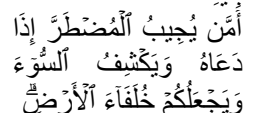 & $\begin{array}{l}\text { QS. Al-Naml } \\
\text { [27]: } 62\end{array}$ \\
\hline 8. & 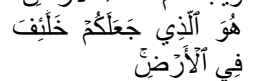 & $\begin{array}{l}\text { QS. Fathir } \\
\text { [35]: } 39\end{array}$ \\
\hline
\end{tabular}

Dari tabel 1 dapat terlihat jelas bahwa ayat Alquran yang menyebutkan kata khalifah secara langsung ada ada 2, yaitu QS. Al-Baqarah [2]: 30 dan QS. Shod [38] : 26. Kedua ayat ini disinyalir sebagai penjelas antara keduanya. Bahkan makna QS. Al-Baqarah [2]: 30 cukup relevan dengan QS. Shod [38]: 26 yang berbunyi,

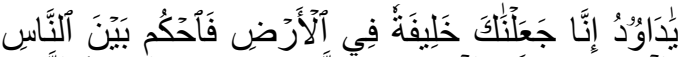

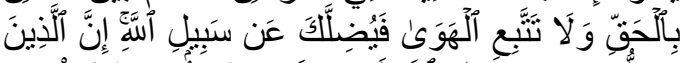

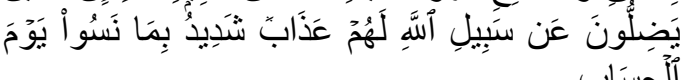

"Hai Daud, sesungguhnya Kami menjadikan kamu khalifah (penguasa) di muka bumi, maka berilah keputusan (perkara) di antara manusia dengan adil dan janganlah kamu mengikuti hawa nafsu, karena ia akan menyesatkan kamu dari jalan Allah. Sesungguhnya orangorang yang sesat darin jalan Allah akan mendapat azab yang berat, karena mereka melupakan hari perhitungan.", dan QS. Al-Nur [24]: 55 yang berbunyi:

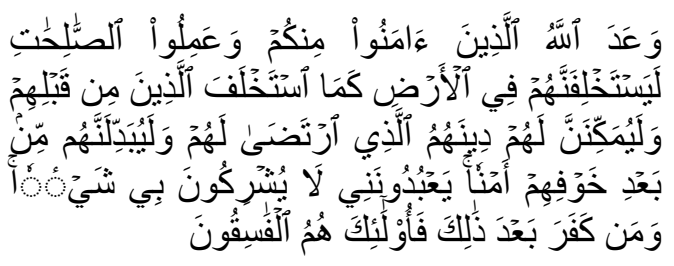

"Dan Allah telah berjanji kepada orangorang yang beriman di antara kamu dan mengerjakan amal-amal yang saleh bahwa Dia sungguh-sungguh akan menjadikan mereka berkuasa dimuka bumi, sebagaimana Dia telah menjadikan orang-orang sebelum mereka berkuasa, dan sungguh Dia akan meneguhkan bagi mereka agama yang telah diridhai-Nya untuk mereka, dan Dia benar-benar akan menukar (keadaan) mereka, sesudah mereka dalam ketakutan menjadi aman sentausa. Mereka tetap menyembahku$\mathrm{Ku}$ dengan tiada mempersekutukan sesuatu apapun dengan Aku. Dan barangsiapa yang (tetap) kafir sesudah (janji) itu, maka mereka itulah orangorang yang fasik."

Muhammad Jamal al-Din al-Qasimi menafsirkan QS. Baqarah [2]: 30 dengan makna 'menjadikan suatu kaum menggantikan sebagian mereka dengan sebagian yang lain, satu generasi sesudah generasi sebelumnya, sebagaimana firman Allah dalam QS. Al-An'am [6]: 165. "Dan Dia-lah yang menjadikan kamu para khalifah (di) bumi." 23

Al-Suyuti dan Al-Mahalli menafsir kata Khalifah pada QS. Al-Baqarah [2]: 30 dengan redaksi "dan ingatlah, hai Muhammad! (Ketika Tuhanmu berfirman kepada para malaikat, "Sesungguhnya Aku hendak menjadikan seorang khalifah di muka bumi") yang akan mewakili Aku dalam melaksanakan hukum-hukum atau peraturan-peraturanKu padanya, yaitu Adam. Artinya yang

\footnotetext{
${ }^{23}$ Muhammad Jamal al-Din al-Qasimi, Tafsir alQasimi al-Musamma Mahasin al-Ta'wil (Kairo: Dar Ihya’ al-Kutub al-‘Arabiyyah, 1957), 94.
} 
dimaksud dengan Khalifah pada ayat ini adalah Nabi Adam As. ${ }^{24}$

Disebutkan juga bahwa kata khalifah yang dimaksud bermakna suatu kaum yang sebagiannya menggantikan sebagian yang lain silih berganti, abad demi abad, dan generasi demi generasi, sebagaimana pengertian yang terkandung dalam ayat-ayat berikut,

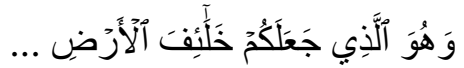

Dan Dialah yang menjadikan kalian penguasa-penguasa di bumi. (QS. AlAn'am [6]: 165.

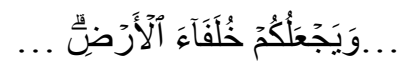

dan yang menjadikan kalian (manusia) sebagai khalifah di bumi. (QS. Al-Naml [27]: 62).

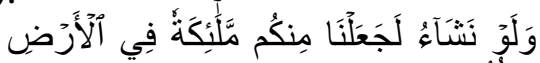

$$
\begin{aligned}
& \text { بَخْلُفُونَ }
\end{aligned}
$$

Dan kalau Kami kehendaki benar-benar Kami jadikan sebagai ganti kalian di muka bumi malaikat-malaikat yang turun-temurun. (QS. Al-Zukhruf [43]: $60)$.

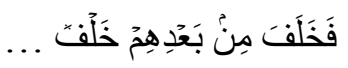

Maka datanglah sesudah mereka generasi lain. (QS. AlA'raf [7]: 169)

Menurut qiraah yang syadz dibaca inni ja'ilun fi al-ardli khalifah (sesungguhnya Aku hendak menjadikan khalifahkhalifah di muka bumi). ${ }^{25}$

Al-Qurtubi mengatakan bahwa yang dimaksud dengan khalifah dalam ayat ini bukan hanya Nabi Adam a.s. seperti yang dikatakan oleh sejumlah ahli tafsir. Al-Qurtubi menisbatkan pendapat ini kepada Ibnu Abbas, Ibnu Mas'ud, dan semua ahli takwil. Akan tetapi, apa yang

\footnotetext{
${ }^{24}$ Jalaluddin al-Suyuṭi dan Jalaluddin al-Maḥalli, Tafsir al-Jalalayn (Kairo: Dār al-Hadith, 2003).

${ }^{25}$ Zamakhshari, Tafsir al-Kashshaf (Beirut: Dar al-Kitab al-'Arabi, t.t.).

${ }^{26}$ Al-Razi, Mafatih al-Ghaib (Beirut: Dar alKitab al-'Arabi, 1407).
}

dikatakan oleh Al-Qurtubi ini masih perlu dipertimbangkan. Bahkan perselisihan dalam masalah ini banyak, menurut riwayat Ar-Razi dalam kitab tafsirnya, juga oleh yang lainnya. ${ }^{26}$ Menurut al-Qurthubi, kata khalifah

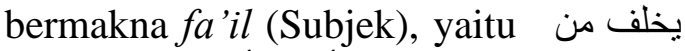
كان قبله من الملائكة في الأرض أو من كان قبله من غير الملائكة على ماروي orang yang sebelumnya berupa malaikat yang menetap di bumi atau atas dasar suatu riwayat orang yang sebelumnya (yang tinggal di bumi) dari selain malaikat.

Makna "khalifah" dalam QS. alBaqarah [2]: 30 ini menurut Ibnu Mas'ud, Ibn 'Abbas dan seluruh pakar tafsir adalah Nabi Adam sebagaimana yang dinyatakan oleh al-Thabari dalam tafsirnya. ${ }^{27}$ Nabi Adam adalah khalifatullah dalam melaksanakan hukum-hukum-Nya dan perintahperintah-Nya, karena ia adalah manusia yang pertama kali diutus oleh Allah ke bumi. $^{28}$

Literasi QS. Al-Baqarah ayat 30 di atas menjadi argumen dalam pengangkatan imam dan khalifah sehingga segala apa yang mereka perintahkan dan segala peraturan hukum yang dibuat oleh mereka wajib ditaati dan dilaksanakan. Tidak ada perbedaan terkait kewajiban itu (mengangkat pemimpin) di antara umat dan para imam, kecuali apa yang diriwayatkan oleh 'Abd al-Rahman Ibn Kaisan yang popular dengan nama al-A'sham (w. 201 H). Ia berkata: "Sesungguhnya (mengangkat) khalifah itu bukan kewajiban dalam agama, yang demikian itu hanyalah merupakan kebolehan.

\footnotetext{
${ }^{27}$ Al-Thabari, Jami' al-Bayan 'an Ta'wil Ayi alQuran (Kairo: Dar al-Fikr, t.t.), 479-80.

${ }^{28} \mathrm{Abi}$ 'Abdillah Muhammad Ibn Ahmad Ibn Abi Bakr al-Qurtubi, Al-Jami' li Ahkam al-Qur'an wa al-Mubayyin li Ma Tadlammanahu min alSunnah wa Ayi al-Furqan (Muassasah alRisalah, 2006), 394-95.
} 
Sesungguhnya apabila umat telah menunaikan haji, jihad mereka dan saling bersikap adil dalam apa yang di antara mereka, memberikan hak dari diri mereka, mereka membagikan ghanimah (harta rampasan perang), fai' dan sedekah kepada yang pantas menerimanya, mereka menegakkan alhudud (sanksi pidana yang ditentukan oleh teks al-Qur'an) kepada orang yang wajib menanggungnya, maka yang demikian itu sudah cukup dan tidak wajib bagi mereka untuk mengangkat imam (pemimpin) untuk menangani semua itu ".

Mencermati interpretasi di atas, sangat jelas bahwa firman Allah dalam QS. Al-Baqarah [2]: 30 menyebut kata "khalifah" bukan dalam pengertian dan tidak pula berkonotasi atau memberikan petunjuk praktis yang jelas untuk menciptakan kepemimpinan (khilafah) politik, sistem pemerintahan atau bentuk Negara dalam Islam.

QS. Al-Baqarah [2]: 30 di atas dan QS. Shad [38]: 26 yakni firman Allah yang artinya, "Hai Daud, sesungguhnya Kami menjadikan kamu sebagai khalifah (penguasa) di muka bumi, maka berilah keputusan (perkara) di antara manusia dengan adil dan janganlah kamu mengikuti hawa nafsu, karena ia akan menyesatkan kamu dari jalan Allah" adalah dua ayat yang paling sering dipakai untuk melegitimasi sistem politik dalam Islam sebagaimana dilakukan HTI dan para pegiat khilafah lainnya. Padahal QS. al-Baqarah [2]: 30 yang menyebut kata khalifah bermakna sebagai khalifatullah (pengganti Allah) dalam memakmurkan bumi melalui peran manusia dengan berbagai kesempurnaan yang melekat padanya. Sedangkan QS. Shad [38]: 26 bermakna lebih menunjukkan kepada tugas untuk memberikan keputusan hukum di antara manusia secara benar dan adil dimana hal ini ditujukan kepada Nabi Daud As.
Jadi, kedua ayat tersebut sama sekali tidak menunjukkan makna "khalifah" sebagai entitas kepemimpinan politik praktis dan sempit tapi merupakan manifestasi dari kepemimpinan absolut Allah pada para wakil dan penggantiNya diatas muka bumi.

Selain kedua ayat yang secara langsung menyebutkan kata khalifah, terma khalifah dan segala derivasinya berbicara tentang kedudukan manusia sebagai makhluk yang saling bergantian menempati dan memakmurkan bumi dari generasi ke generasi berikutnya, atau dalam makna pergantian siang malam, dan perpedaan pendapat.

Kata khalfun dalam pengertian "generasi pengganti yang berperilaku buruk". Disebutkan dua kali yaitu pada surat al A'raf ayat 169 dan surat Maryam ayat 59. Pada QS. Al-A'raf [7]: 169 disebutkan.

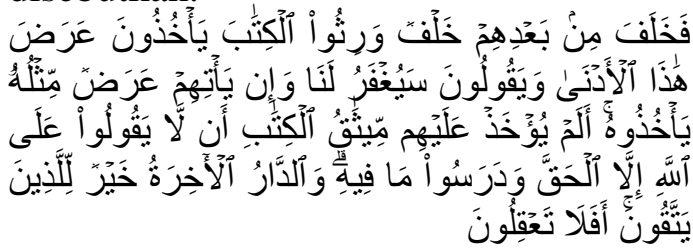

"Maka datanglah sesudah mereka generasi (yang jahat) yang mewarisi Taurat, yang mengambil harta benda dunia yang rendah ini, dan berkata: "Kami akan diberi ampun." Dan kelak jika datang kepada mereka harta benda dunia sebanyak itu (pula), niscaya mereka akan mengambilnya (juga). Bukankah perjanjian Taurat sudah diambil dari mereka, yaitu bahwa mereka tidak akan mengatakan terhadap Allah kecuali yang benar, padahal mereka telah mempelajari apa yang tersebut di dalamnya?. Dan kampung akhirat itu lebih baik bagi mereka yang bertakwa. Maka apakah kamu sekalian tidak mengerti?"

Pada QS. Maryam [19]: 59 dikatakan,

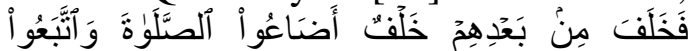

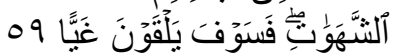


"Maka datanglah sesudah mereka, pengganti (yang jelek) yang menyianyiakan shalat dan memperturutkan hawa nafsunya, maka mereka kelak akan menemui kesesatan".

Yang dimaksud dengangenerasi yang jahat pada ayat pertama di atas menunjuk kepada generasi yang datang sesudah masa dan generasi para Nabi dan Rasul di kalangan Bani Israil. Mereka adalah generasi yang mempermainkan hukum Allah dan memperjual belikannya ayat-ayatnya dengan keuntungan materi. Di antaranya dengan menyelewengkan hukum melalui penyuapan (risywah) dan korupsi dalam kekuasaan. Sedang generasi yang buruk pada ayat kedua di atas menunjukan generasi yang datang seduah masa generasi para nabi dan orang-orang saleh dari kalangan Bani Israil, dan termasuk juga generasi yang buruk yang datang pada umat Nabi Muhammad di akhir zaman. Mereka adalah generasi yang meninggalkan shalat dan tenggelam dalam pemuasan berbagai kesenangan dunia. ${ }^{29}$

Kata khulafa' (bentuk plural maknawi tidak beraturan dari kata khalifah, ${ }^{30}$ yang berarti generasi baru atau kaum pengganti yang mewarisi bumi dari kaum sebelumnya yang binasakan karena mereka tidak beriman.

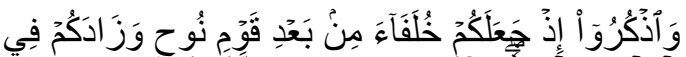

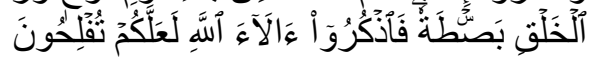

"Dan ingatlah oleh kamu sekalian di waktu Allah menjadikan kamu sebagai pengganti-pengganti (yang berkuasa) sesudah lenyapnya kaum Nuh, dan Tuhan telah melebihkan kekuatan tubuh dan perawakanmu (dari pada kaum Nuh itu). Maka ingatlah nikmat-nikmat Allah

${ }^{29}$ Ibnu Katsir, Tafsir al Qur'an al 'Adhim (Darut Thayibah, 1999), 245. supaya kamu mendapat keberuntungan”. (QS. Al-A'raf [7]: 69).

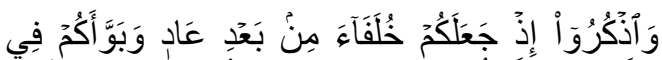

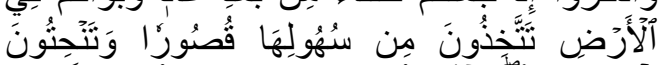

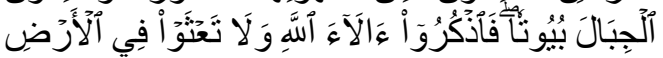

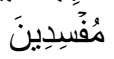

"Dan ingatlah olehmu di waktu Tuhan menjadikam kamu pengganti-pengganti (yang berkuasa) sesudah kaum 'Aad dan memberikan tempat bagimu di bumi. Kamu dirikan istana-istana di tanahtanahnya yang datar dan kamu pahat gunung-gunungnya untuk dijadikan rumah; maka ingatlah nikmat-nikmat Allah dan janganlah kamu merajalela di muka bumi membuat kerusakan." (QS. Al-A'raf [7]: 74).

Kemudian kata al-Khalaif (bentuk jamak lafdzi dari kata khalifah), yang berarti kaum yang datang untuk menggantikan kaum yang lain dalam menempati dan menguasai bumi. ${ }^{31}$

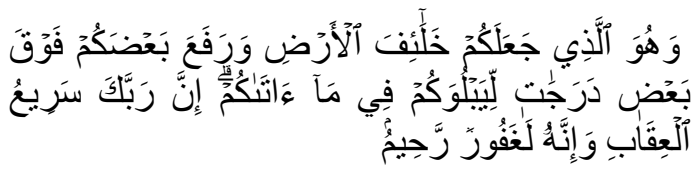

"Dan Dia lah yang menjadikan kamu penguasa-penguasa di bumi dan Dia meninggikan sebahagian kamu atas sebahagian (yang lain) beberapa derajat, untuk mengujimu tentang apa yang diberikan-Nya kepadamu. Sesungguhnya Tuhanmu amat cepat siksaan-Nya dan sesungguhnya Dia Maha Pengampun lagi Maha Penyayang”. (QS. Al-An'a>m [129]: 165).

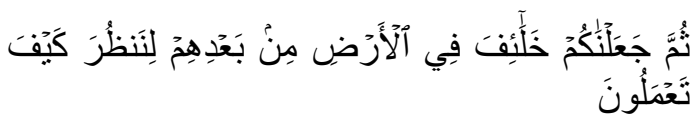
"Kemudian Kami jadikan kamu pengganti-pengganti (mereka) di muka bumi sesudah mereka, supaya Kami

\footnotetext{
${ }^{30}$ Syamsuddin Al-Qurtubi, Al-Jami' li Ahkam alQur'an, 7 ed. (Kairo: Dar al-Kutub alMishriyyah, 1964), 236.

${ }^{31}$ Syamsuddin Al-Qurtubi, 158.
} 
memperhatikan bagaimana kamu berbuat". (QS. Yunus [10]: 14).

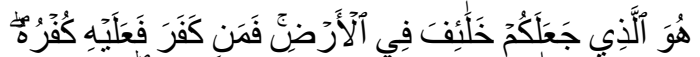

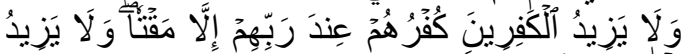

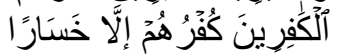

"Dia-lah yang menjadikan kamu khalifah-khalifah di muka bumi. Barangsiapa yang kafir, maka (akibat) kekafirannya menimpa dirinya sendiri. Dan kekafiran orang-orang yang kafir itu tidak lain hanyalah akan menambah kemurkaan pada sisi Tuhannya dan kekafiran orang-orang yang kafir itu tidak lain hanyalah akan menambah kerugian mereka belaka”. (QS. Fathir [35]: 39).

Kata Khalifah dengan bentuk mufrad (singular) dalam pengertian seseorang yang diberi mandat kekuasaan oleh Allah sebagai penguasa bumi dan pemimpin terhadap manusia lainnya. Istilah Khalifah dalam bentuk singular disebutkan Alquran sebanyak dua kali, yaitu ketika menyebutkan kedudukan Nabi Adam dan Nabi Dawud, yaitu pada QS. Al-Baqarah [2]: 30 dan QS. Shod [38]: 26

Pada bentuk verba istakhlafa, diartikan dengan 'menjadikan seseorang atau satu kaum sebagai khalifah, para pemimpin, pewarits dan penguasa bumi setelah kaum yang lain, sebagaimana QS. Al-Nur [24]: 55.

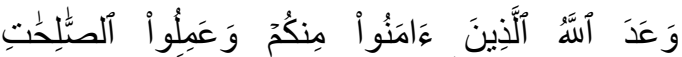

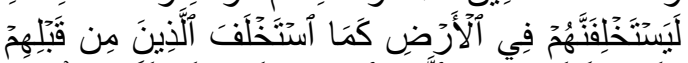

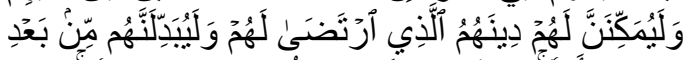

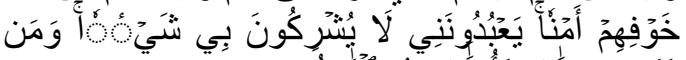

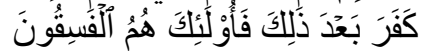

"Dan Allah telah berjanji kepada orangorang yang beriman di antara kamu dan mengerjakan amal-amal yang saleh bahwa Dia sungguh-sungguh akan menjadikan mereka (para khalifah) berkuasa dimuka bumi, sebagaimana
Dia telah menjadikan orang-orang sebelum mereka berkuasa, dan sungguh Dia akan meneguhkan bagi mereka agama yang telah diridhai-Nya untuk mereka, dan Dia benar-benar akan menukar (keadaan) mereka, sesudah mereka dalam ketakutan menjadi aman sentausa. Mereka tetap menyembahku$K u$ dengan tiada mempersekutukan sesuatu apapun dengan Aku. Dan barangsiapa yang (tetap) kafir sesudah (janji) itu, maka mereka itulah orangorang yang fasik".

Kata mustakhlaf (bentuk objek dari istakhlafa) bermakna orang-orang yang dijadikan pewaris bumi dan diberi kewenangan atau mandat untuk menguasainya, untuk menunjukan bahwa penguasaan manusia terhadap dunia adalah penguasaan nisbi dan majazi, karena penguasa dan pemilik hakikinya hanyalah Allah. ${ }^{32}$

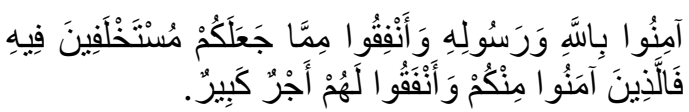
"Berimanlah kamu kepada Allah dan Rasul-Nya dan nafkahkanlah sebagian dari hartamu yang Allah telah menjadikan kamu menguasainya. Maka orang-orang yang beriman di antara kamu dan menafkahkan (sebagian) dari hartanya memperoleh pahala yang besar". (QS. Al-Hadid [57]: 71).

Selain dalam Al-Quran, kata khalifah juga banyak disebutkan dan Hadis. Dalam Hadis Nabi, penyebutan kata khalifah atau khulafa' lebih banyak dari pada yang disebutkan dalam $\mathrm{Al}$ Qur'an dengan makna yang lebih tegas terhadap kepemimpinan, diantaranya adalah Hadis:

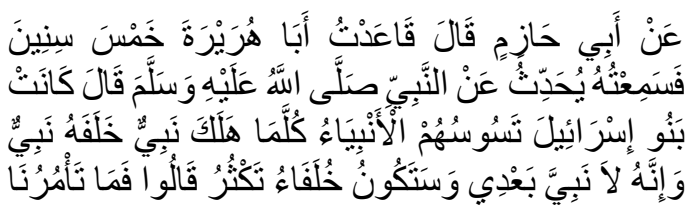

${ }^{32}$ Syamsuddin Al-Qurtubi, 238. 


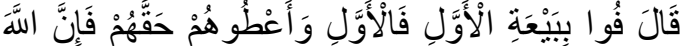

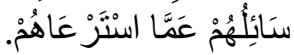

"Dari Abu Hazim dia berkata, "Saya pernah duduk (menjadi murid) Abu Hurairah selama lima tahun, saya pernah mendengar dia menceritakan dari Rasulullah shallallahu 'alaihi wasallam, beliau bersabda: "Dahulu Bani Israil selalu dipimpin oleh para Nabi, setiap Nabi meninggal maka akan digantikan oleh Nabi yang lain sesudahnya. Dan sungguh, tidak akan ada Nabi lagi setelahku, namun yang ada adalah para khalifah (kepala pemerintahan) yang merekan akan banyak berbuat dosa." Para sahabat bertanya, "Apa yang anda perintahkan untuk kami jika itu terjadi?" beliau menjawab: "Tepatilah baiat yang pertama, kemudian yang sesudah itu. Dan penuhilah hak mereka, kerana Allah akan meminta pertanggung jawaban mereka tentang pemerintahan mereka." ${ }^{\prime 33}$

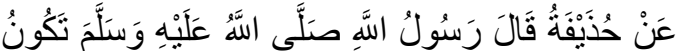

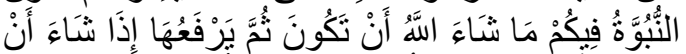

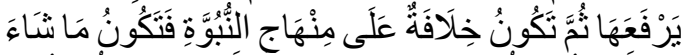

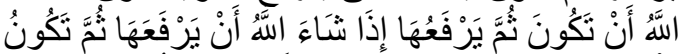

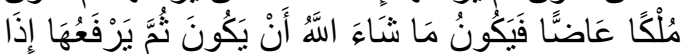

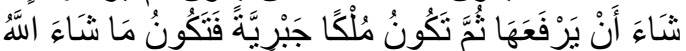

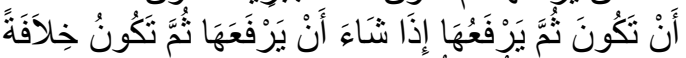

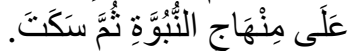

"Dari Hudzaifah, Rasulullah bersabda, "Di tengah-tengah kalian ada Kenabian dan akan berlangsung sekehendak Allah. Lalu Allah akan mengangkatnya jika Dia berkehendak mengangkatnya. Kemudian akan ada Khilafah berdasar manhaj kenabian dan berlangsung sekendak-Nya. Kemudian Allah akan

${ }^{33}$ Muslim, Shahih Muslim (Beirut: Dar al-Fikr, t.t.), 3429; Al-Bukhori, Shahih Bukhari (Kairo: Dar al-Taqwa, t.t.), 3196; Ahmad Ibn Hambal, Musnad Ahmad (Kairo: Dar al-Taqwa, t.t.), 7619; Ibnu Majah, Sunan Ibnu Majah, 2862 ed. (Kairo: Dar al-Taqwa, t.t.), 2862.

${ }^{34}$ Ahmad Ibn Hambal, Musnad Ahmad, 18406. mengangkatnya jika Dia menghendakinya. Kemudian akan ada Kerajaan yang lalim yang berlangsung sekehendak Allah. Kemudian Allah akan mengangkatnya jika Dia menghendakinya. Kemudian akan ada Kerajaan yang Otoriter berlangsung sekendak Allah. Kemudian Dia akan mengangkatnya jika Dia menghendakinya. Kemudian akan ada Khilafah berdasar manhaj kenabian". Kemudian beliau (Nabi SAW) diam. ${ }^{34}$

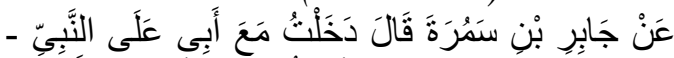

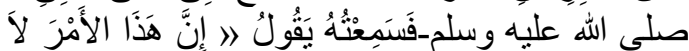

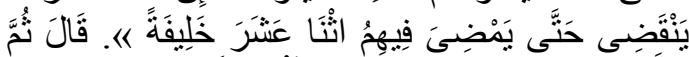

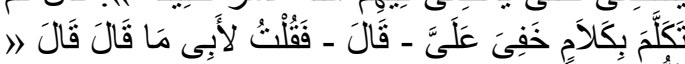

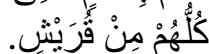

"Dari Jabir Ibn Samurah, Aku bersama bapakku masuk kepada Nabi, maka aku mendengar beliau bersabda, "Sesungguhnya urusan (Agama Islam) ini tidak akan berakhir sampai berlangsung di tengah mereka dua belas khalifah". Kemudian beliau berkata dengan perkataan yang samar bagiku. Maka Aku bertanya kepada ayahku apa yang disabdakan beliau? Ayahku menjawab, "Semuanya dari Quraisy". 35

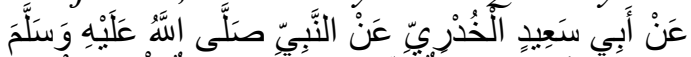

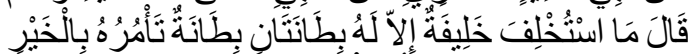

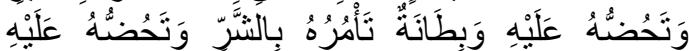

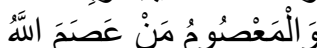

"Dari Abu Said al Hudri, dari nabi SAW.

"Tidaklah seorang khalifah diangkat melainkan ia mempunyai dua teman setia. Teman setia yang menyuruh dengan kebaikan dan teman setia yang menyuruh dengan keburukan dan menganjurkannya. Orang yang terpelihara adalah ia yang dipelihara Allah." 36

\footnotetext{
${ }^{35}$ Muslim, Shahih Muslim, 4809; Muslim dan Abu Dawud, Shahih Muslim, Sunan Abu Dawud (Beirut: Dar al-Kutub, t.t.), 4279.

${ }^{36}$ Al-Bukhori, Shahih Bukhari, 6611; Al-Tirmizi, Sunan Tirmidzi (Beirut: Dar al-Kutub, t.th), 2474.
} 
Dari beberapa ayat dan Hadis di atas, dapat disimpulkan bahwa Allah telah menetapkan manusia sebagai khalifah di bumi. Pengertian kekhalifahan manusia di muka bumi mencakup dua makna; makna yang umum dan makna yang khusus. Secara umum seluruh manusia adalah khalifah karena ia makhluk yang dipilih Allah sebagai penguasa dan pemimpin atas makhluk lainnya yang ada di muka bumi. Manusia juga sebagai khalifah karena setiap orang, kaum dan bangsa datang dan pergi, hidup dan mati, berjaya dan hancur, saling bergantian antara satu generasi dengan generasi berikutnya. Kekhilafahan seperti ini dapat diistilahkan sebagai khilafah takwiniyyah, kekhilafahan manusia di muka bumi sebagai ketetapan atau takdir kehidupan yang Allah gariskan bagi manusia, baik ia manusia beriman ataupun manusia kafir.

Al-Baidlowi menjelaskan bahwa khalifah bermakna mewakilkan kepada wakilnya, khalifah dalam ayat tersebut adalah Nabi Adam sebagai khalifatullah di muka bumi sebagaimana nabi-nabi lain yang diutus Allah sebagai wakilNya untuk memakmurkan dan melaksanakan hukum-hukum-Nya di muka bumi. ${ }^{37}$ Sedang menurut alZamakhshari, khalifah adalah orang yang mengganti yang lain. ${ }^{38}$ Ibnu Kathir menjelaskan bahwa wakil Tuhan di muka bumi ini bukan hanya ditujukan pada Adam saja, sebagaimana pendapat para mufasir, melainkan ditujukan secara umum, yakni kepada kaum. ${ }^{39}$ Artinya, QS. Al-Baqarah [2]: 30 tidak hanya terbatas kepada Adam jika di dukung dengan keberadaan QS. al-A'rāf [7]: 69,

\footnotetext{
${ }^{37}$ Al-Baidlowi, Anwar al-Tanzil wa Asrar alTa wil (Beirut: Dar al-Fikr, 1991).

${ }^{38} \mathrm{Al}$-Zamakhshari, Al-Kashshaf 'an Haqā'iq alTanzil wa 'Uyun al-Aqawi al-Wujuh al-Ta'wil, Mesir: Mustafa al-Bab al-Halābi, 1972.

و الخليفة: من يخلف غيره. و المعنى خليفة منكم، لأنهم كانو اسكان فئان

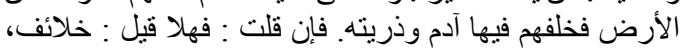
أو خلفاء؟ قلت: أريد بالخليفة آدم. واستغني فأني بذكره عن ذكر بنيه
}

QS: Yunus [10]: 14, dan QS: Al-Naml [27]: 62, maka QS. Al-Baqarah [2]: 30 juga ditujukan kepada anak cucu Adam.

M. Quraish Shihab mengatakan bahwa khalifah pada mulanya berarti "yang menggantikan" atau "yang datang sesudah siapa yang datang sebelumnya'. Atas dasar ini, ada yang memahami kata khalifah di sini dalam arti yang menggantikan Allah dalam menegakkan kehendak-Nya dan menerapkan ketetapan-ketetapan-Nya, bukan karena Allah tidak mampu atau menjadikan manusia berkedudukan sebagai Tuhan. Dengan pengangkatan itu Allah bermaksud menguji manusia dan memberinya penghormatan. Ada juga yang memahaminya dalam arti 'yang menggantikan makhluk lain dalam menghuni bumi ini' ${ }^{40}$

Thabathaba'i juga mengatakan bahwa khilafah bermakna khilafah 'an Allah, yakni 'pengganti, dalam arti makhluk yang mendapat kepercayaan sebagai wakil Allah di muka bumi untuk menjalankan kehendak-Nya dan menerapkan ketetapan-ketetapan-Nya. Fungsi kekhalifahan ialah mengatur, menundukkan, dan memanfaatkan benda-benda ciptaan Allah di muka bumi ini sesuai dengan maksud diciptakannya. Hal ini sesuai dengan makna yang و علم terkandung dalam ayat berikutnya "Dan Allah mengajarkan kepada Adam nama-nama.)". Pada ayat tersebut yang dimaksud dengan Adam bukan Adam sebagai pribadi, akan tetapi Adam dan keturunannya yaitu manusia pada umumnya. Khilafah dalam ayat tersebut diperuntukkan bagi manusia pada umumnya. Bahwa khilafah itu

\footnotetext{
كما استغنى بذكر أبي القبيلة في قولك: مضر و هاثم. أو أريد من

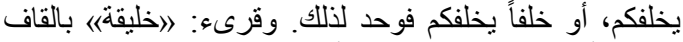

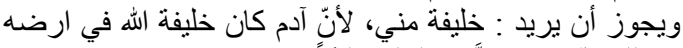

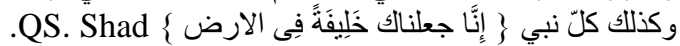
[38]:26

${ }^{39}$ Ibnu Kathir, Tafsir al-Quran al-Azim, t.t., 257.

${ }^{40}$ M. Quraish Shihab, Tafsir Al-Mishbah (Jakarta: Lentera Hati, 2011), 140.
} 
mengandung arti umum juga diperkuat إذ جعلكم خلفاء من بعد ثم جعلناكم : قوم نوح و خلائف في الأرض (QS. Al-Naml [27] : 62). ${ }^{41}$

Al-Thabari menjelaskan bahwa ada perbedaan pendapat di kalangan para ahli takwil. Pertama, bahwa penghuni bumi yang pertama adalah makhluk Jin, kemudian makhluk Iblis. Karena kedua makhluk ini selalu menyebar kerusakan, menumpahkan darah, dan saling membunuh, maka Allah menciptakan Adam dan keturunannya sebagai pengganti untuk memakmurkan bumi. Kedua, bermaksud menggantikan sebagian atas sebagian, yakni anak-anak akan menggantikan ayah mereka, setiap generasi akan menggantikan generasi sebelumnya. Ketiga, Allah menjadikan makhluknya di muka bumi sebagai khalifah untuk melaksanakan peraturanNya di antara makhluk-Nya. Keempat, Allah menjadikan makhluknya di muka bumi sebagai khalifah untuk melaksanakan hukum di kalangan makhluk-Nya. Wakil yang dimaksud adalah Adam dan keturunannya yang taat kepada Allah agar menetapkan hukum dengan adil. ${ }^{42}$

Sementara itu, menurut M. Quraish Shihab, QS. Al-Baqarah [2]: 30 di atas menginformasikan unsur-unsur kekhalifahan sekaligus kewajiban bagi khalifah. Unsur-unsur tersebut adalah pertama, bumi atau wilayah. Kedua, khalifah (yang diberi kekuasaan atau mandataris). Ketiga, hubungan antara pemilik kekuasaan dengan wilayah, dan

\footnotetext{
${ }^{41}$ Thaba'taba'I, Tafsir Al-Mizan, t.t., 375.

${ }^{42}$ Al-Thabari, Jami' al-Bayan fi Tafsir Ayi alQuran (Beirut: Dar al-Fikr, 1990).

${ }^{43} \mathrm{M}$ Quraish Sihab, Membumikan al-Qur'an Fungsi dan Peran Wahyu dalam Kehidupan Masyarakat, 2002.

${ }^{44}$ Al-Tabrasi, Majma' al-Bayan fi Tafsir alQuran (Kairo: Dar al-Kutub 'Ilmiyyah, 1995).
}

hubungannya dengan pemberi
kekuasaan Allah. ${ }^{43}$
Sementara itu, terma lain dalam

Sementara itu, terma lain dalam khalifah adalah kata imamah. ${ }^{44}$ Kata imamah dan ummah berasal dari kata yang sama amm yang berarti 'kehendak atau maksud'. Kemudian dari akar kata ini kemudian terbentuk kata imam yang berarti 'orang yang diikuti dan imamah kekuasaan atau kekuasaan yang diikuti' ${ }^{45}$ Kata ini dalam Alquran disebut sebanyak 7 kali dan hanya dua ayat yang dapat dikategorikan dengan pemimpin, yaitu pada QS: Al-Baqarāh [2]: 124 dan QS. Al-Furqan [25]: 74. M. Quraish Shihab sependapat dengan atTabrāsi yang menyamakan istilah imām dengan khalifah. Namun ia memberi catatan bahwa kata imam digunakan untuk keteladanan karena terambil dari makna 'depan', sedangkan khalifah terambil dari makna "belakang". 46 Khalid Ibrahim Jindan mengatakan dua istilah tersebut dapat digunakan secara timbal balik, kecuali yang memerlukan penjelasan khusus. ${ }^{47}$

Makna khilafah secara khusus, yaitu kekhalifahan dalam pengertian kepemimpinan seseorang atas manusia yang lain. Kekhilafahan dalam makna ini tentu saja tidak mungkin ditujukan kepada semua manusia, bahkan tidak setiap orang beriman dapat menduduki kekhilafahan ini, terlebih lagi orangorang kafir. Hanya orang-orang yang memenuhi kriteria tertentu yang telah diatur oleh syariat yang berhak menjabatnya. Kekhilafahan dalam makna ini identik dengan imamah atau

\footnotetext{
${ }^{45}$ M. Quraish Shihab, Wawasan al-Qur'an (Bandung: Mizan, 1996).

${ }^{46} \mathrm{M}$ Quraish Sihab, Membumikan al-Qur'an Fungsi dan Peran Wahyu dalam Kehidupan Masyarakat.

${ }^{47}$ Khalid Ibrahim Jindan, Teori Politik Islam (Telaah kritis Ibnu Taimiyah Tentang Pemerintahan Islam) (Surabaya: Risalah Gusti, 1995).
} 
kepemimpinan formal dalam masyarakat dan negeri muslim. Kekhilafahan dalam makna ini pula yang dimaksud dalam hadits-hadits Nabi yang berbicara tentang kepemimpinan Islam. Atas dasar itu, kekhilafahan dalam konteks ini dapat diistilahkan sebagai khilafah shar'iyyah kepemimpinan berdasarkan syariat Islam.

Kekhalifahan pada umat Islam adalah kepemimpinan sebagai pengganti dan pelanjut kepemimpinan kenabian, karenanya ia disebut sebagai khilafah 'ala minhaj al-nubuwwah. Dengan demikian, khalifah adalah khalifaturrasul (pengganti dan pelanjut kepemimpinan nabi) bukan khalifatullah (pengganti atau wakil Allah).

Sebagaimana dikatakan oleh AlMawardi bahwa Imamah terma untuk khilafah nubuwwah dalam menjaga agama dan menata dunia"48

Jika kata khilafah itu disandarkan kepada Allah (khalifatullah), maka maknanya adalah penghormatan dan kemuliaan dari Allah yang diberikan kepada hamba-hamba pilihannya, bukan sebagai pengganti dan wakil Allah di muka bumi. Tidak ada satu makhluk yang dapat menempati, menggantikan, dan mewakili Allah. Sebagaimana dikatakan Al-Raghib al-Isfahani bahwa khilafah merupakan perwakilan dari yang lain. Adakalanya (perwakilan itu) disebabkan ketiadaan orang yang diwakilinya, karena kematiannya, atau karena kelemahannya. Adakalanya juga karena sebagai penghormatan atas orang yang disuruh mewakilinya. Makna terakhir inilah yang dimaksud Allah menjadikan khalifah para kekasih-Nya di muka bumi". 49

Alquran dan Hadis tidak menetapkan bentuk, format, maupun prosedur yang

\footnotetext{
48،Ali Ibn Muhammad Al-Mawardi, Al-Ahkam
} al-Sultaniyyah wa al-Wilayah al-Diniyyah, 3. baku tentang negara khilafah, akan tetapi para ulama menyatakan bahwa kekhilafahan dibangun berdasarkan prinsip musyawarah, keadilan, kesamaan, penegakan hukum syariat, dan kemaslahatan umat. Dari semua itu prinsip dasarnya adalah penegakan hukum syariat secara konsisten dan konsekwen berdasarkan Kitabullah dan Sunnah Rasulullah untuk mencapai kemaslahatan hidup manusia di dunia dan akhirat. Ibnu Khaldun juga menyatakan bahwa khilafah adalah menggiring seluruh (manusia) kepada yang sesuai dengan tinjauan syar'i dalam kemaslahatan ukhrawi, dan kemaslahatan duniawi mereka yang kembali kepadanya (kepada kemaslahatan akhirat). Sebab segala kemaslahatan urusan dunia menurut syariat harus ditinjau berdasarkan kemaslahatan akhirat". 50

Oleh karena itu, jika kepimpinan atau pemerintahan itu menggunakan terma kekhilafahan Islam, tetapi jika syariat tidak dilaksanakan, kezaliman dan kekejaman merajalela, maka tidak patut disebut sebagai kepemimpinan khilafah yang syar'i, melainkan sebagai kepemimpinan raja-raja otoriter yang memeras rakyat). Sebaliknya meskipun suatu kepemimpinan dan pemerintahan berbentuk kerajaan, republik, atau yang lainnya, maka ia dikatakan sebagai khilafah dan pemimpinya layak disebut sebagai Khalifah atau Amirul mukminin. Sebagaimana Allah memanggil Nabi Dawud sebagai Khalifah meskipun beliau berkedudukan sebagai Nabi dan Raja Bani Israil. Begitu pula Umar Ibn Abdul Aziz, dalam pemerintahan Dinasti Umayah, dan Harun Al Rasyid dalam Dinasti Abasiyah, meskipun keduanya dipilih bukan berdasarkan syura seperti

\footnotetext{
${ }^{49}$ Al-Raghib Al-Isfahani, Mu'jam Mufradat Alfazh Al-Qur'ani, 156.

${ }^{50}$ Ibnu Khaldun, Muqaddimah, 97.
} 
para Khulafaur Rasyidin, keduanya diakui sebagai Khalifah dan Amirul Mukminin.

Penyebutan "akan ada khalifahkhaifah yang banyak' menunjukan bahwa mereka bukanlah Khulafa Rasyidin sebab jumlah Khulafa Rasyidin tidaklah banyak. Demikian pula pernyataan, 'tunaikanah baiat pertama dan pertama' bahwa para khalifah tersebut berselisih sedangkan para Khulafa Rasyidun tidaklah berselisih. Sedang pernyataan, 'berikanlah hak mereka karena mereka akan diminta pertanggungjawaban tentag rakyatnya', menjadi dalil atas madzhab ahlussunnah tentang memberikan hak-hak para pemimpin dari harta dan ghanimah sebagimana saya telah menjelaskan bukan hanya di tempat ini saja, bahwa mengambalikan segala persoalan kepada para raja dan pembantunya dari para pemimpin dan qadhi bukan semata karena kekurangan (kelemahan dan keburukan) yang ada pada mereka saja, melainkan kekurangan (kelemahan) itu juga ada pada rakyat secara bersamasama, sebab sebagaimana dikatakan (dalam hadits), 'sebagaimana keadaan kalian, seperti itulah pemimpin kalian'. Allah berfirman, 'demikianlah kami jadikan orang-orang zalim sebagai pemimpin atas sebagian yang lainnya". 51

Relasi lain kata khalifah dalam Alquran adalah kata uli al-amri yang bermakna 'pemimpin atau kepemimpinan'. Kata ini dalam Alquran terulang sebanyak dua kali QS. Al-Nisa' [4]: 59, 83. Sejarah mencatat terkait dengan penafsiran terhadap ayat 59 tersebut sarat dengan nuansa politis, khususnya terkait dengan masa penghapusan kekhalifahan Turki Usmani di Turki pada tahun 1924.

Khalifah berarti wakil (deputy), penggantian (successor), penguasa

\footnotetext{
${ }^{51}$ Ibnu Taimiyah, Al-Khilfah wa al-Muluk dalam Majmu' Fatawa, 20.
}

(vicegerent), titel bagi pemimpin tertinggi komunitas muslim sebagai pengganti nabi. Khilafah merupakan istilah ketatanegaraan Islam, dan berarti kepala negara atau pemimpin tertinggi umat Islam. Istilah khalifah pertama kali muncul di Arab pra-Islam dalam suatu prasasti Arab abad ke-6 M. Kata khalifah dalam prasasti ini menunjuk kepada semacam raja atau letnan yang bertindak sebagai wakil pemilik kedaulatan yang berada di tempat lain. Istilah ini dalam kesejarahan Islam digunakan dalam bentuk khalifah ar-Rasul. ${ }^{52}$

Oleh karena itu, perkembangan makna khalifah suatu hal yang niscaya, sebab khilafah adalah sebutan untuk masa pemerintahan khalifah. Selain itu, sudah menjadi fitrah bagi manusia yang terdorong untuk membangun kekuasaan bagi kepentingan untuk mengatur kehidupan politiknya. Sejarah telah mencatat bahwa setelah wafatnya nabi institusi politik yang dilembagakan secara formal dan disebut dengan khalifah. Abu Bakar sendiri, sebagai khlaifah pertama, menyebut dirinya sebagai pengganti rasul untuk melaksanakan dan menjaga dari warisan nabi. Dalam hal ini, sejalan dengan perkembangan makna khalifah, titel khalifah dalam diri Abu Bakar dapat juga berarti sebagai pengatur, penguasa, yang memimpin masyarakat. Dalam perkembangannya, sebutan ini menjadi konvensi yang mapan dan berkembang lebih jauh pada dinasti-dinasti yang pengaruh Arabnya kuat, seperti Abasiyyah, Umayah, dan Fatimah. Kelembagaan ini secara formal disebut khilafah dan pelakunya disebut khalifah. Adapun ras lain seperti di India, Iran, Persia, Turki mengunakan istilah Imam, Amir, Sultan. Keengganan mereka menyandang khalifah diduga karena masalah politis, di mana mereka menilai

\footnotetext{
${ }^{52}$ M. Quraish Shihab, "Ensiklopedi al-Qur`an: Khalifah," dalam Ulumul Qur`an, t.t., 206.
} 
khalifah hanya monopoli orang-orang Quraisy.

Konteks Histori dan Kronologi

Selanjutnya dalam konteks sejarah, QS. Al-Baqarah [2]: 30 sebenarnya menyebutkan bahwa Allah SWT menetapkan manusia sebagai khalifahNya dan menjelaskan tentang derajat sepiritual yang dimiliki oleh manusia disisi Allah diantara makhluk-makhluk lainnya dan secara eksklusif dalam ayat tersebut diidentikkan dengan bapak manusia yaitu Adam AS, yang dengan segala potensinya dapat memanifestasikan seluruh asma dan sifatnya di tengah-tengah kehidupan umat manusia yang melampaui derajat sekalipun para malaikat.

Dalam Tafsir Al-Amtsal, Makarim Shirazi menguraikan terma Khalifah dengan makna 'pengganti dari yang lain' dengan mengutip adanya ragam pandangan dari sebagian para mufassir tentang siapa yang digantikan. Ada yang memaknainya dengan 'pengganti para malaikat yang sebelumnya hidup menguasai bumi', dan atau 'pengganti umat manusia sebelumnya atau makhluk-makhluk lain yang sebelumnya berada di bumi'. Sebagian yang lain juga memaknai Khalifah dengan 'setiap generasi umat menusia yang menggantikan generasi sebelumnya'. Namun, Makarim Shirazi lebih memilih prespektif sebagaimana mayoritas para peneliti yang membenarkan dengan memaknaim Khalifah dengan khalifatullah yaitu 'pengganti Allah di bumi, karena munasabah maknanya berkorelasi lebih tepat dengan pengertian kembali kepada wujud manusia yang berderajat tinggi yaitu Adam AS, kepadanya diajarkan oleh Allah secara langsung tentang seluruh

${ }^{53}$ Makarim Shirazi, Al-Amthal fi Tafsir Kitabillah al-Munzal (Madrasah Imam Ali Ibn ABi Thalib, 1426), 131. nama (asma) dan kemudian para Malaikat diperintahkan oleh Allah untuk bersujud kepada Adam AS. ${ }^{53}$

Begitu juga halnya dengan Taba'tabai yang berpandangan bahwa Khalifah nisbatnya adalah kepada Allah (khalifatullah), dan jawaban atas pertanyaan Malaikat tentang potensi manusia yang akan membuat kerusakan di bumi dan menyebabkan pertumpahan darah menegasikan kebenaran nisbat kepada selain-Nya, Allah menjawab pertanyaan itu, bahwa Dia lebih mengetahui atas kehendak-Nya atas potensi manusia dengan ilmu tentang seluruh asma yang telah diajarkan kepadanya dalam hal ini adalah kepada Nabi Adam As. Inilah yang akan membuatnya mampu melampoi potensi Malaikat. Thaba'thabai juga menggarisbawahi bahwa kedudukan spiritual yang agung ini tidak eksklusif terbatas pada Nabi Adam saja tetapi juga anak-anak Adam lainnya yang sesuai dengan potensi-potensinya, dan prespektif ini dikuatkan dengan beberapa ayat yang dia nukil dari QS. Al-A'raf [7]: 69, Yunus [10]: 14 dan alNaml [27]:62.

Tentang kriteria khalifatullah, Taba'thab'i menguraikannya secara substansial beranjak dari konsep Khilafah yang bermakna keberadaan manusia menggantikan kedudukan selainnya, Khalifah tidak representatif jika tidak identik dengan yang digantikannya dalam semua kriteria wujud diri pengganti, dalam jejakjejaknya, dalam hukum dan kebijaksanaannya, termasuk dalam otoritas yang dia pegang, sedangkan Allah Dzat yang identik dengan asma husna dan sifat-sifat yang maha mulia, maha indah dan maha perkasa, maha suci dari segala kekurangan, maha kudus dari 
segala perbuatan yang buruk dan fasad, Dialah Keagungan Mutlak. Lantas layakkah manusia menjadi sebagai khalifah-Nya ?.

Oleh karena manusia tercipta dari tanah dengan penuh kenistaan, Malaikat memohon penjelasan dari Allah tentang eksistensi manusia yang akan menempati bumi, tiada lain dipandang hanya sebatas speises material yang yang tersusun dari potensi emosional (alquwwah al-ghadlabiyyah) dan shahwat (al-Shahwiyyah). Bumi merupakan medan tinggal yang membuat manusia saling berdesakan dengan orientasi yang terbatas, penuh dengan gesekan, terdiri dari susunan unsur yang rapuh, sistemnya dalam bahaya kehancuran, kehidupan di dalamnya tidak ideal dan semu, hidup tidak bertahan kecuali dengan bersosialisasi dan saling membantu, berpotensi mengalamai kehancuran dan terjadi pertumpahan darah. Hal ini dinilai subjektif dan diragukan oleh Malaikat, bahwa manusia tidak mampu menggantikan otoritas Allah di atas muka bumi ?. ${ }^{54}$

\section{Konteks Kontemporer}

Pada konteks kontemporer ini, diitegrasikan penafsiran tekstual dan kontekstual dengan melalu empat tahapan sebagai berikut.

1. Memahami Tujuan QS. Al-Baqarah: 30

Sebelum membahas aspek-aspek yang lain dalam menafsirkan QS. AlBaqarah [2]: 30, tahapan awal yang harus diungkap adalah apa sebenarnya tujuan ayat tersebut. Menilik kembali literasi ayat tersebut, terlihat jelas bahwa tujuan ayat ini adalah menegaskan tentang kepemimpinan Absolut pada hak Allah yang menetapkan sistem kepemimpinan di muka bumi sebagai khalifah (pengganti) yang dapat memanifestasikan asma dan sifatsifat-Nya di antara semua makhluk selainnya. Bahkan lebih spesifik lagi, bahwa ayat ini bertujuan untuk menetapkan bahwa manusia pilihan sebagai khalifatullah bukan manusia secara umum tapi adalah manusia terpilih yang makshum yang senantiasa ada dalam setiap generasi umat manusia, dan dalam hal ini di ayat yang dimaksud terimplemantasi dalam wujud bapak manusia yaitu Nabi Adam As.

2. Melepaskan Subjektifitas (Lokalitas) Tempat, Masa, dan Oknum

Dalam konteks kontemporer, interpretasi logis kata khalifah dalam QS. Al-Baqarah [2]:30, subjektifitas ayat yang relevan adalah bahwa petunjuk yang dikandung oleh kata khalifah harus dilepaskan. Kata khalifah kini tidak lagi bicara konteks subjek Nabi Adam As dan hal-hal yang terkait dengannya, namun menjelaskan perannya sebagai pelajaran-pelajaran yang penting bagi generasi umat manusia terkait konsep khilafah.

Relevansi khalifah dengan kriteriakreterianya senantiasa ada di tengahtengah generasi umat manusia, dalam hal ini Allah Swt menegaskannya dalam QS. Al-An'am [6]: 165.

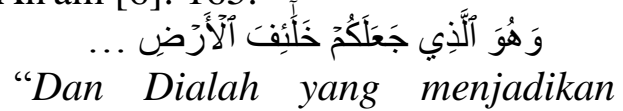
kalian khalifah-khalifah di bumi.", begitu juga di QS. Al-Naml [27]: 62, ........

"Dan yang menjadikan kalian sebagai khalifah-khalifah di bumi."

Demikian itu sebagai konsekwensi dari kehendak-Nya secara sistemik

\footnotetext{
54 Muhammad Husayn Ṭabāṭabā‘̄̄e al-Mīzān fì Tafsìr al-Qur'ān (Kairo: Dar al-Fikr, 1992), 114-15.
} 
menjadikan di setiap kaum dan generasi terdapat seorang utusan dan pemberi petunjuk ilahiah

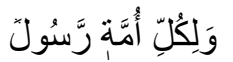

"Tiap-tiap umat mempunyai rasul". (QS. Yunus [10]: 47)

$$
\text { وَلِكُلِّ قَوْمٍ هَادِ }
$$

"Tan bagi tiap-tiap kaum ada orang yang memberi petunjuk" (AlRa'ad[13]:7)

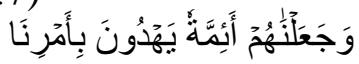

"Kami telah menjadikan mereka itu sebagai pemimpin-pemimpin yang memberi petunjuk dengan perintah Kami”'(QS. Al-Anbiya'[21]:73).

3. Mengambil Kaidah Universal Ayat Kaidah universal yang dapat diambil dari nalar logika tafsir QS. Al-Baqarah [2]: 30 ini terangkum dalam beberapa poin berikut:

a) Khalifatullah di atas muka bumi adalah manusia sempurna yang mampu mengekstrak asma dan sifat yang digantikannya (Allah) dalam eksistensi dirinya. Bukan semua manusia karena bisa jadi derajat mereka ada yang bahkan jatuh melebihi kehinaan dari pada binatang yang tidak berakal. QS. Al-A'raf [7]: 179 (كاولئك ) (كالانعام بل هم اضلّ

b) Allah menciptakan alam semesta beserta isinya dengan sistem kausalitas di dalamnya bukan berarti karena membutuhkan pada sebab-sebab, namun justeru demikian itu menjadikannnya sebagai faktor kemulyaan bagi manusia, sehingga semua sebab yang ada menjadi dalam otoritas manusia.

c) Ilmu ghaib hanya milik Allah sebagaimana QS. Yunus [10]:20 dan sebagiannya dengan kehendak-Nya

${ }^{55}$ Al-Qurtubi, Tafsir al-Jami' 'i Ahkam al-Qur'an (Beirut: Dar al-Kitab al-Arabi, 2008). dianugerahkan kepada hambahamb-Nya yang khusus sebagaimana QS. Al-Nahl [16]:

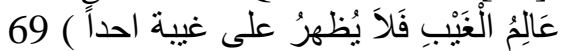

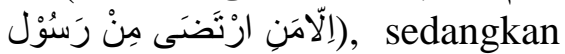
Khalifatullah merupakan sebab dan media yang khusus dan tertentu dengan semua tugasnya yang definitif.

4. Menerapkan pada Objek Baru

Interprteasi kata Khalifah dalam QS. Al-Baqarah [2]: 30 jika diterapkan dengan konteks dan isu di Indonesia terkait isu negara Islam (Dawlah Islamiyyah) yang digaung-gaungkan oleh HTI sangat tidak sesuai dan relevan.

Dari tahapan interprtasi integratif dan kontekstual kata khilafah, dapat terlihat jelas bahwa kata Khalifah dalam QS. AlBaqarah [2]: 30 yang dijadikan argumen kuat oleh Hizbuttahrir di Indonesia tentang konsep Khilafah yang ingin diterapkan di Indonesia sangat tidak sesuai dan tidak relevan. Bahkan mereka telah salah kaprah mengutip Tafsir alQurtubi ${ }^{55}$ Pada kitab tafsir lain terkait QS. al-Baqarah [2]: 30 tidak ditemukan 'tafsir politis', sebab ayat ini menjelaskan proses pengangkatan Nabi Adam sebagai خليفة الله في الارض).

NKRI, tidak dapat dibubarkan dengan alasan membentuk ulang negara dengan sistem khilafah. UUD 1945 Pasal 37 ayat 5 menegaskan "Khusus tentang bentuk Negara Kesatuan Republik Indonesia tidak dapat dilakukan perubahan."

Oleh karena itu, argumen HTI terhadap QS. Al-Baqarah [2]: 30 sebagai dasar kewajiban mendirikan Khilafah sebagai sistem politik Indonesia sangat tidak tepat dan salah alamat. Kewajiban mengangkat pemimpin adalah satu hal, cara memilih pemimpin adalah persoalan lain. Indonesia bukan negara 
Islam (dar al-islam), akan tetapi negara kesepakatan (dar al-'ahdi).

\section{Kesimpulan}

Dari pembahasan yang ada, dapat disimpulkan bahwa dengan tahapan berfikir kontekstual integratif mulai dari konteks literal, kronologi, hukum, hingga konteks kontemporer dapat ditemukan interpretasi kontekstual integratif kata Khalifah pada QS. AlBaqarah [2]: 30 adalah bahwa manusia pilihan sebagai khalifatullah bukan manusia secara umum tapi adalah manusia terpilih yang suci yang senantiasa ada dalam setiap generasi umat manusia, dan dalam hal ini di ayat yang dimaksud terimplemantasi dalam wujud Nabi Adam As. Artinya, interprtasi ini sangat tidak relevan dengan konsep khilafah yang diperjuangkan oleh Hizbuttahrir di Indonesia.

\section{Daftar Pustaka}

A. W. Munawwir. "Kamus AlMunawwir." Surabaya: Pustaka Progresif, 1997.

Abdul Qadim Zalum. Nizam al-Hukm fi al-Islam. Dar al-Ummah, 2002.

Abdullah 'Umar Sulaiman Al-Dumaiji. Abdullah 'Umar Sulaiman AlDumaiji, Al-Imamah Al'Uzama' 'Inda Ahli al-Sunnah wal Jama'ah 1987. Kairo, 1987.

Abdurrahman al-Dimishqiyyah. Hizb al-Tahrir. Lebanon: Dar alUmmat, 1985.

Abi 'Abdillah Muhammad Ibn Ahmad Ibn Abi Bakr al-Qurtubi. AlJami' li Ahkam al-Qur'an wa alMubayyin li Ma Tadlammanahu min al-Sunnah wa Ayi alFurqan. Muassasah al-Risalah, 2006.

Ahmad Ibn 'Ali Al-Qalaqsandi. Ma'atsir al-Inafah fi Ma'alim al-Khilafah. Kuwait, 1964.
Ahmad Ibn Hambal. Musnad Ahmad. Kairo: Dar al-Taqwa, t.t.

Ahmad Ramadlan Ahmad. Al-Khilafah $f i$ al-Hadlarah al-Islamiyyah. Jedah: Dar al-Bayan Al'Arabiyyah, t.t.

Al-Baidlowi. Anwār al-Tanzil wa Asrar al-Ta'wil. Beirut: Dar al-Fikr, 1991.

Al-Bukhori. Shahih Bukhari. Kairo: Dar al-Taqwa, t.t.

Al-Fairuzabadi. Al-Qamus al-Muhith. Muassasah al-Risalah, 2009.

- Basair Dhawi al-Tamyiz fi Lathaifi Kitab al-'Aziiz. AlMajlis al-A'la li al-Shu'un alIslamiyyah, 1996.

'Ali Ibn Muhammad Al-Mawardi. AlAhkam al-Sultaniyyah wa alWilayah al-Diniyyah. Kuwait, 1989.

Al-Jauhari. Al-Sahhah fi al-Lughah. Kairo: Dar al-Hadith, t.t.

Al-Qurtubi. Tafsir al-Jami' li Ahkam alQur'an. Beirut: Dar al-Kitab alArabi, 2008.

Al-Raghib Al-Isfahani. Mu'jam Mufradat Alfazh Al-Qur'ani. Damaskus: Dar al-Qalam, 1416.

Al-Razi. Mafatih al-Ghaib. Beirut: Dar al-Kitab al-'Arabi, 1407.

Al-Samin al-Halibi. 'Umdah alHuuffazh. Beirut: Dar al-Kutub, 2000.

Al-Tabrasi. Majma' al-Bayan fi Tafsir al-Quran. Kairo: Dar al-Kutub 'Ilmiyyah, 1995.

Al-Thabari. Jami' al-Bayan 'an Ta'wil Ayi al-Quran. Kairo: Dar alFikr, t.t.

_. Jami' al-Bayan fi Tafsir Ayi alQuran. Beirut: Dar al-Fikr, 1990.

Al-Tirmizi. Sunan Tirmidzi. Beirut: Dar al-Kutub, t.th.

Britain, Hizbut Tahrir. The Method to Re-Estasblish the Khilafah and Resume the Islamic Way of Life. 
London: al-Khilafah

Publication, 2000.

Hizbuttahrir. Ajhizah Daulah alKhilifah fi al-Hukm wa alIdarah. Beirut-Lebanon: Dar alUmmah, 2005.

Ibn Faris. Maqayis al-Lughah. Beirut: Dar al-Fikr, t.t.

Ibn Manzur. "Lisan al-'Arab." Mesir: Dar al-Misriyyah, t.t.

Ibnu Faris, dan Ahmad Ibn Zakaria. Maqayis al-Lugahahro. Kairo: Dar al-Hadith, 2008.

Ibnu Hajar Al-Haitami. Al-Sawa'iq alMuhriqah. Beirut: Dar al-Kutub 'Ilmiyyah, 2000.

Ibnu Hazm. Al-Fashl fi Al-Milal wa alAhwa' wa al-Nihal. Beirut: Dār Kutub al-'Ilmiyyah, 1999.

Ibnu Katsir. Tafsir al Qur'an al 'Adhim. Darut Thayibah, 1999.

Ibnu Khaldun. Muqaddimah. Beirut: Dar al-Qalam, 1984.

Ibnu Majah. Sunan Ibnu Majah. 2862 ed. Kairo: Dar al-Taqwa, t.t.

Ibnu Taimiyah. Al-Khilfah wa al-Muluk dalam Majmu' Fatawa, t.t.

Jalāluddīn al-Suyuṭi, dan Jalaluddin alMaḥallī. Tafsīr al-Jalālayn. Kairo: Dār al-Hadīth, 2003.

Kathir, Ibnu. Tafsir al-Quran al-Azim, t.t.

Khalid Ibrahim Jindan. Teori Politik Islam (Telaah kritis Ibnu Taimiyah Tentang Pemerintahan Islam). Surabaya: Risalah Gusti, 1995.

M. Quraish Shihab. "Ensiklopedi alQur`an: Khalifah.” Dalam Ulumul Qur`an. Vol. VI, t.t. . Tafsir Al-Mishbah. Jakarta: Lentera Hati, 2011.
. Wawasan al-Qur'an. Bandung: Mizan, 1996.

M Quraish Sihab. Membumikan alQur'an Fungsi dan Peran Wahyu dalam Kehidupan Masyarakat, 2002.

Makarim Shirazi. Al-Amthal fi Tafsir Kitabillah al-Munzal. Madrasah Imam Ali Ibn ABi Thalib, 1426.

Muhammad Hasan Jabal. Al-Mu'jam Al-Ishtiqaqi al-Muasshal. Beirut: Dar al-Fikr, 2000.

Muhammad Husayn Thaba'țaba'i. alMizan fi Tafsir al-Qur'an. Kairo: Dar al-Fikr, 1992.

Muhammad Ibrahim al-Khafnawi. Mu'jam Gharib al-Figh wa alUshu. Kairo: Dar al-Hadith, 2009.

Muhammad Jamal al-Din al-Qasimi. Tafsir al-Qasimi al-Musamma Mahasin al-Ta'wil. Kairo: Dar Ihya' al-Kutub al-'Arabiyyah, 1957.

Muslim. Shahih Muslim. Beirut: Dar alFikr, t.t.

Muslim, dan Abu Dawud. Shahih Muslim, Sunan Abu Dawud. 4809, 4279 vol. Beirut: Dar alKutub, t.t.

Syamsuddin Al-Qurtubi. Al-Jami' li Ahkam al-Qur'an. 7 ed. Kairo: Dar al-Kutub al-Mishriyyah, 1964.

Taba'taba'i. Tafsir Al-Mizan, t.t.

"Website Resmi HTI." Diakses 14 Agustus 2018. https://hizbuttahrir.org/.

Zamakhshari. Tafsir al-Kashshaf. Beirut: Dar al-Kitab al-'Arabi, t.t. 